PODPORA KRITICKĚHO MYŠLENÍ A POUŽÍVANÍ AKTIVIZAČNÍCH METOD VE VÝUCE OŠETŘOVATELSTVÍ

\title{
THE SUPPORT OF CRITICAL THINKING AND USING ACTIVATION METHODS IN EDUCATION BY STUDENTS OF NURSING
}

\author{
*Magda Taliánová, **Martin Forejt \\ *Katedra ošetřovatelství, Fakulta zdravotnických studií, \\ Univerzita Pardubice \\ * Ústav preventivního lékařství, Lékařská fakulta, Masarykova \\ univerzita Brno
}

\section{Souhrn}

Příspěvek popisuje používání aktivizačních metod při výuce ošetřovatelství. Kromě třífazového modelu označovaného V češtině zkratkou EUR (evokace - uvědomění si významu reflexe) zde uvádím také příklady metod, které je možné v jednotlivých fázích využít a to jak ze strany učiteli̊ ošetřovatelství, tak i sester podílejících se na výuce či edukaci klientů. Uvádím také výsledky výzkumu zaměřeného na aktivizaci ve výuce jako jeden z pilíř̉ kritického myšlení.

\section{Summary}

My report describes using activation methodes in education of nursing. In addition to a three-phase model known, in Czech, as EUR model (evocation - awareness - reflection), I present examples of methods that can be used in individual phases of the model by nursing teachers as well as participating in student and client education. Finally, I present results of research that focused on activation methods in education as one of the pillars of critical thinking. 


\section{Klíčová slova}

kritické myšlení, aktivizační metody ve výuce, model EUR, kognitivní dovednosti, metakognitivní dovednosti, ošetřovatelství, studenti

\section{Key words}

critical thinking, activation methods in education, EUR model, cognitive skills, metacognitive skills, nursing, students

\section{Úvod}

od každé budoucí sestry se očekává, že její odborné znalosti a dovednosti budou založeny na samostatnosti, odpovědnosti, tvořivosti, kritickém myšlení, individuálních perspektivách a společenských požadavcích. Aby mohly být kvalitně prováděny ošetřovatelské činnosti, musíme u studentů podněcovat kritické myšlení, sociální a praktické dovednosti. (Grecmanová et al., 2000, s. 8)

Kritické myšlení je schopnost posoudit nové informace, pozorně a kriticky je zkoumat z více perspektiv, tvořit si úsudky o jejich věrohodnosti a hodnotě, posoudit význam nových myšlenek a informací pro vlastní potřeby. (Gavora, 1988, s. 661-672) Každá sestra může kritické myšlení uplatnit $v$ těchto oblastech:

- Při identifikaci potencionálního nebo aktuálního problému

- V návrhu a realizaci opatření, které mohou vzniklý problém odstranit

- Během hodnocení ošetřovatelské péče

- U zvyšování kvality péče

- V rámci snižování rizika nežádoucích situací a problémů 
- Pro zlepšení komunikace s členy zdravotnického týmu, pacienty, rodinnými či blízkými příslušníky. (Škrla, Škrlová, 2003, s. 477)

\section{Tř́fazový model učení - EUR}

Důležitou součástí kritického myšlení je třífázový model učení (evokace - uvědomění si významu - reflexe) zahrnující kromě myšlenkových procesů také rozhodování, řešení problémů a metodické aspekty. (Steel et al., 1997, s. 5, s. 18)

1. Evokace - je první fází výše uvedeného modelu, při které by mělo každé učení začínat tím, že si studenti uvědomí a slovy vyjádří to, co o předloženém tématu vědí či co si o tom myslí. Přitom také formulují nejasnosti a otázky, které k danému tématu mají a na něž budou hledat odpověd' v další fázi modelu. V této fázi je možné využít např. metody brainstorming, myšlenková mapa.

- Brainstorming (mozková bouře) - smyslem metody je vyprodukovat co nejvíce nápadi̊ a potom posoudit jejich užitečnost. Optimální počet studentů nebo klientů pro tuto metodu je 7-12 a optimální čas 30-45 minut. Učitel nebo sestra stanoví problém a poté začíná produkce nápadů. Zapisují se všechny nápady, které se v druhé části mozkové bouře vyhodnotí dle stanovených kritérií. Nehodící nápady se škrtnou a ze zbylých se zformuluje nejlepší řešení daného problému.

- Myšlenková mapa - učitel nebo sestra napíše na tabuli do kruhu slovo nebo tezi. Studenty/klienty poté vyzve, aby k ústřednímu slovu napsali všechny svoje myšlenky a znalosti. Nápady se zakroužkují a spojí čarou s ústředním slovem či tezí. Přínos této metody spočívá v tom, že u studentů či klientů dojde k uvědomění si 
vztahů a souvislostí mezi danými jevy. (Špirudová et al., 2005, s. 200)

2. Uvědomění si významu je druhou fází modelu, během které dochází ke konfrontaci studentova pưvodního konceptu předloženého tématu se zdrojem nových informací, názorů a souvislostí. V průběhu této fáze lze využít např. ano-ne metodu, INSERT, skupinové vyučování.

- Ano-ne - učitel/sestra připraví pro studenty či klienty tabulku s výroky. Jsou-li přesvědčeni, že je věta pravdivá napíší ano, v opačném případě odpoví ne. Poté se vyloží nová látka a na závěr se zkontrolují odpovědi.

a I.N.S.E.R.T. je systém záznamů s jejichž pomocí si studenti v učebním textu označují informace jim známe, rozporné, neznáme, atd. Učitel nebo sestra předloží studentům či klientům text, který si studenti/klienti musí pozorně přečíst. Při čtení student/klient označí informace $v$ textu symboly tak, že známé myšlenky zatrhne "fajfkou", nové informace symbolem +, myšlenky s nimiž nesouhlasí -, myšlenky, o kterých by se chtěl ještě něco dozvědět označí ?. (Špirudová et al., 2005, s. 202)

a Skupinové vyučování - je založeno na spolupráci studentů/klientů při řešení úkolů a na odpovědnosti za výsledky společné práce. Metodu lze využít jak při nácviku jednoduchých dovedností, tak i při řešení složitých problému a plnění náročných úkolů.

3. Reflexe je poslední fáze modelu EUR, při které studenti/klienti přeformulují své chápání předloženého tématu na základě nových informací. Uvědomí si, co nového se naučili a co se jim z pưvodních představ potvrdilo či vyvrátilo. Uvědomí si názory a postoje druhých lidí. Zde je 
možné využít některou z následujících metod např. diskuse, volné psaní. (Špirudová et al., 2005, s. 208)

- Diskuse je vzájemná komunikace mezi učitelem/sestrou a studentem/klientem nebo mezi studenty/klienty při řešení nějaké otázky či vyjasnění problému. Předpokladem úspěšné diskuse je vhodně upravená místnost, příprava diskutujících na dané téma, myšlenková vyspělost a důvěra mezi účastníky.

- Volné psaní - úkolem studentů/klientů je během 5 minut napsat k tématu všechny svoje myšlenky a znalosti. Ačkoliv vyjádření musí být v celých větách, není nutné se zabývat gramatickou a stylistickou stránkou psaného textu.

Aktivizace ve výuce přispívá k rozvoji kritického myšlení. V další části přispěvku uvádím některé výsledky, které vypovídají o tom, jak učitelé aktivizují studenty ve výuce.

\section{Cíl práce}

Hlavním cílem šetření bylo zjistit, zda učitelé ošetřovatelství na oslovených školách upřednostñují tradiční nebo aktivizační výukové metody. Dílčím cílem bylo zjistit, zda má délka pedagogické praxe vliv na využívání aktivizačních metod, zda učitelé na středních zdravotnických školách (SZŠ) dávají přednost aktivizačním metodám častěji než učitelé na vyšších odborných školách (VOŠ) a vysokých školách (VŠ) a zda jsou při využívání aktivizačních metod ve výuce rozdíly mezi učiteli a učitelkami.

\section{Soubor a metodika}

Rozdáno bylo 220 dotazníků se stoprocentní návratností a z toho 211 dotazníků zpracováno a 9 pro neúplnost vyřazeno. 
Výzkumného šetření se tedy zúčastnilo 211 respondentů vyučujících na szŠ, VOŠ a VŠ ve východočeském a středočeském kraji se zaměřením na ošetřovatelství. Vzhledem k tomu, že mě zajímalo, jak učitelé ošetřovatelství využívají aktivizačních metod při výuce, pokusila jsem se provést výzkumnou sondu do této oblasti. K získání dat jsem použila metodu dotazníku. Výzkum probíhal v letech 2005-2006. K vyhodnocování dat jsem použila relativní četnost a k ověření platnosti hypotéz test dobré shody chí-kvadrát $(\mathrm{P}-\mathrm{O})^{2} / 0$, kde $\mathrm{P}$ je pozorovaná četnost a o je očekávaná četnost. Hodnocení jsem prováděla v 5\% hladině významnosti.

\section{Výsledky}

Hypotéza 1: Četnost používání aktivizačnich metod je vyšší u učitelek než u učitelů.

Šetření se zúčastnilo 73,5\% žen a 26,5\% mužů. Ze všech dotazovaných učitelů používá aktivizační metody pouze 12 (21,4\%) učitelů, kdežto ze všech dotazovaných učitelek upřednostňuje aktivizační metody ve výuce 86 (55,4\%). Tato hypotéza se mi potvrdila, nebot hodnota testového kritéria $\mathrm{X}^{2}=15,5$ je vyšši než kritická hodnota $\mathrm{X}^{2}=3,841$ pro 1 stupeň volnosti.

\section{Hypotéza 2: Učitelé dávají přednost tradičním výukovým metodám} před aktivizačními výukovými metodami.

Tradičním výukovým metodám dává přednost 53,5\% ze všech dotazovaných.

Tato hypotéza se mi nepotvrdila ze statistického hlediska, nebot' hodnota testového kritéria $x^{2}=1,06$ je menší než kritická hodnota $x^{2}=3,841$ pro 1 stupeň volnosti. 
V tab. 1 je uveden počet učitelů používajících při výuce aktivizační nebo tradiční výukové metody dle typu škol.

Tab. 1 Preference používaných výukových metod dle typu školy

\begin{tabular}{|c|c|c|c|c|c|c|}
\hline & \multicolumn{2}{|c|}{ szŠ } & \multicolumn{2}{|c|}{ VŠ, VOŠ } & \multicolumn{2}{|c|}{ Celkem } \\
\hline & $\begin{array}{c}\text { absolutní } \\
\text { četnost }\end{array}$ & $\begin{array}{l}\text { relativní } \\
\text { četnost (\%) }\end{array}$ & $\begin{array}{c}\text { absolutní } \\
\text { četnost }\end{array}$ & $\begin{array}{l}\text { relativní } \\
\text { četnost (\%) }\end{array}$ & $\begin{array}{c}\text { absolutní } \\
\text { četnost }\end{array}$ & $\begin{array}{l}\text { relativní } \\
\text { četnost }\left(\frac{\circ}{\circ}\right)\end{array}$ \\
\hline $\begin{array}{l}\text { Tradiční } \\
\text { metody }\end{array}$ & 74 & 53,2 & 39 & 54,1 & 113 & 53,5 \\
\hline $\begin{array}{c}\text { Aktivizační } \\
\text { metody }\end{array}$ & 65 & 46,8 & 33 & 45,9 & 98 & 46,5 \\
\hline Celkem & 139 & 100 & 72 & 100 & 211 & 100 \\
\hline
\end{tabular}

Hypotéza 3: Četnost používání aktivizačnich metod je vyšší u učitelů na SZŠ než u učitelů na VŠ a Voš.

Tato hypotéza se mi nepotvrdila vzhledem k tomu, že hodnota testového kritéria $x^{2}=3,69$ je menší než kritická hodnota $X^{2}=3,841$ pro 1 stupeñ volnosti.

\section{Hypotéza 4: Aktivizační metody většinou použili pedagogové s pedagogickou praxí kratší 10 let.}

Pedagogickou praxi delší než 10 let mělo 145 učitelů $(68,7 \%)$. 36,5\% učitelů s praxí delší než 10 let použilo aktivizační metody. Pedagogickou praxi kratší než 10 let mělo 66 učitelů $(31,2 \%)$. 68,1\% z dotazovaných učitelů jejichž praxe je kratší než 10 let odpovědělo, že použilo aktivizační metody. Tato hypotéza se mi potvrdila, protože hodnota testového kritéria $x^{2}=10,1$ je větší než kritická hodnota $x^{2}=3,841$ pro 1 stupeň volnosti.

Níže uvedený graf 1 ukazuje přehled aktivizačních metod dle oblíbenosti učitelů. 


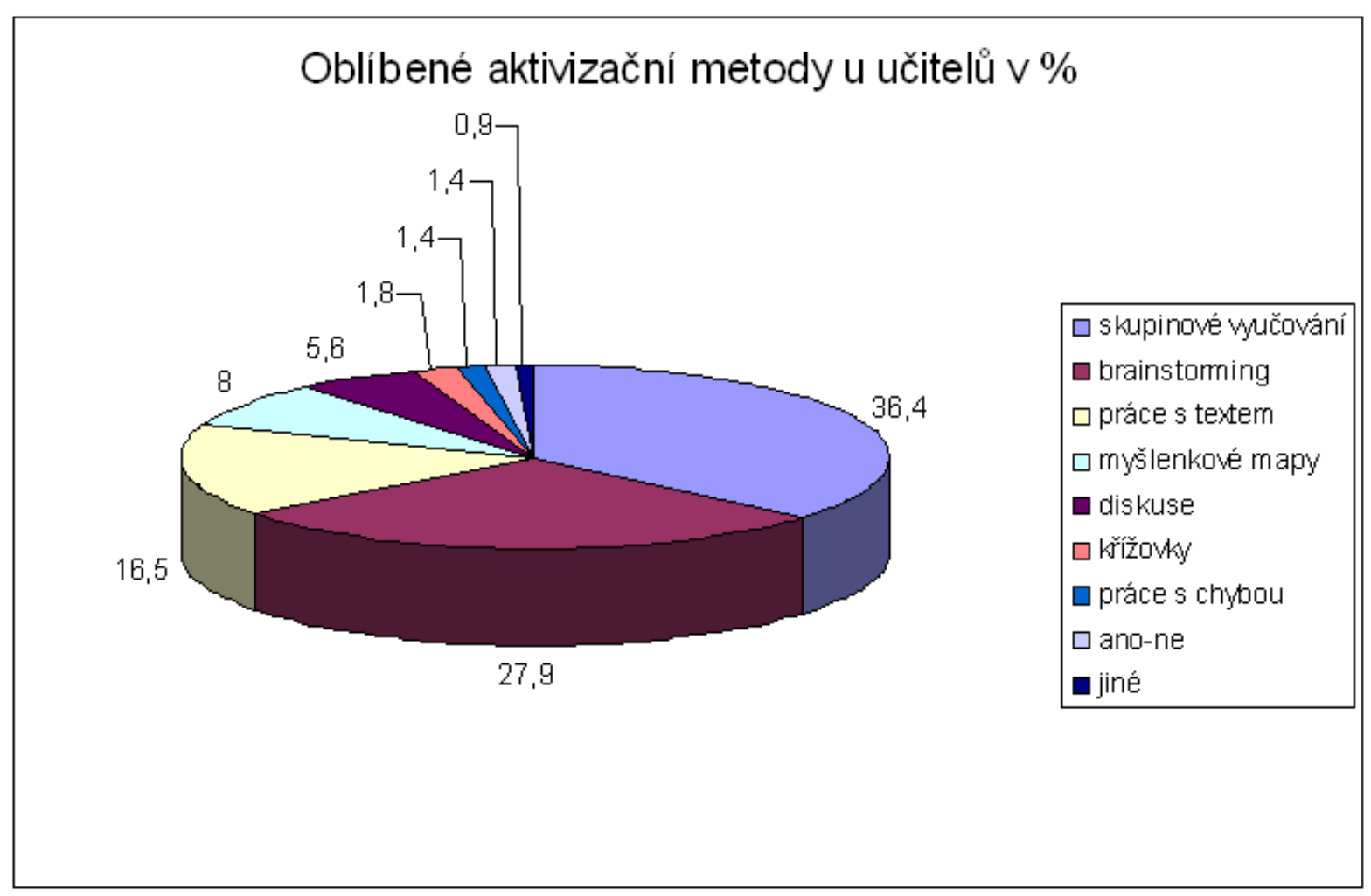

Obr. 1 Graf Nejoblíbenější aktivizační metody z pohledu učitelů

K nejoblíbenějším metodám celkově u dotazovaných učitelů (viz graf 1) se řadí: skupinové vyučování (36,4\%), brainstorming (27,9\%), práce s textem (16,5\%), myšlenkové mapy (8\%), diskuse $(5,6 \%)$, křížovky $(1,8 \%)$, práce s chybou (1,4\%), ano-ne (1,4\%) a jiné $(0,9 \%)$.

Následující graf 2 zobrazuje aktivizační metody, které jsou u žáků oblíbené z pohledu učitele. 


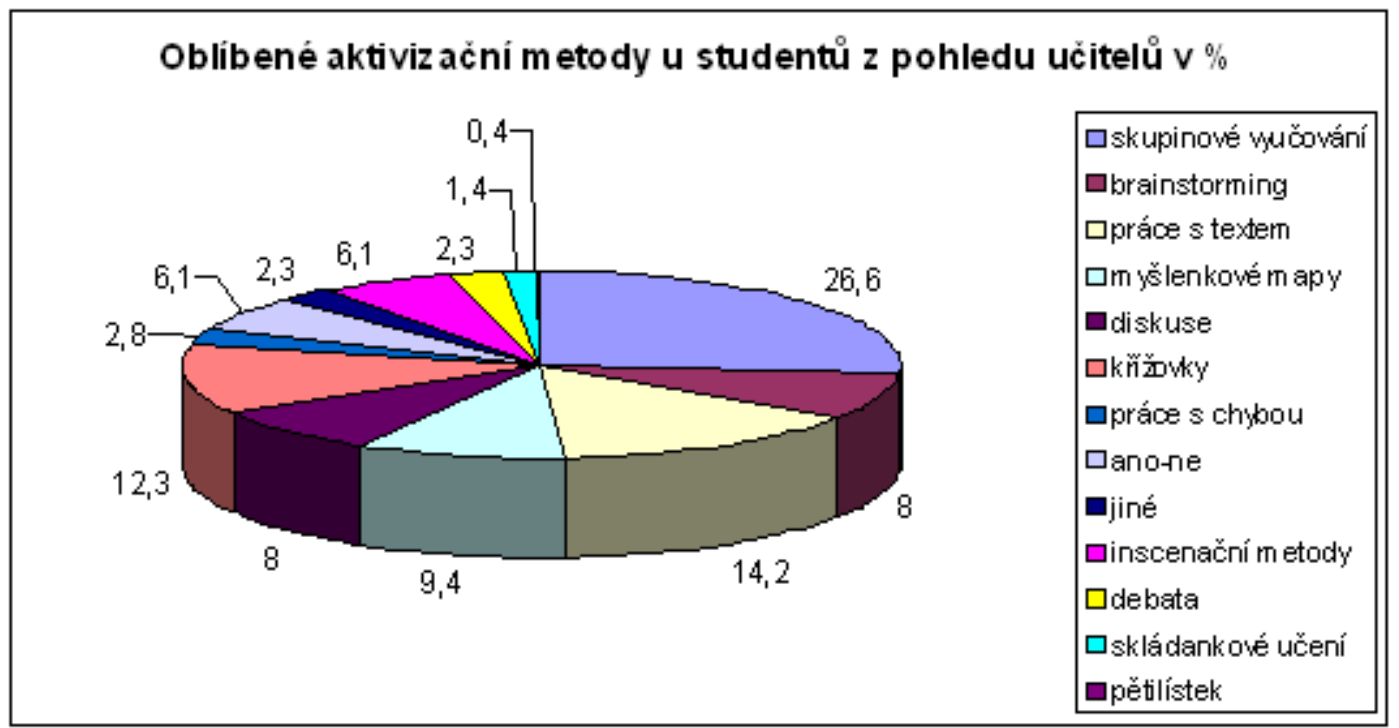

Obr. 2 Graf Oblíbené aktivizační metody u žáků z pohledu učitelů

Celkově (viz graf 2) měly dle učitelů u studentů největší ohlas tyto metody: skupinové vyučování $(26,6 \%)$, práce s textem $(14,2 \%)$, křížovky $(12,3 \%)$, myšlenkové mapy $(9$,4\%), diskuse (8\%), brainstorming ( $8 \%)$, ano-ne $(6,1 \%)$, inscenační metody $(6,1 \%)$, práce s chybou $(2,8 \%)$, debata $(2,3 \%)$, jiné metody $\left(2,3 \frac{0}{0}\right)$, skládankové učení $(1,4 \%)$, pětilístek $(0,4 \%)$. K metodám, které učitelé nepoužívají, protože jsou u studentů neoblíbené, patří vizualizace textu a puzzle.

\section{Diskuse a závěr}

Jako nejpoužívanější a nejoblíbenější metoda bylo učiteli i studenty vybráno skupinové vyučování, dále pak brainstorming, práce s textem, myšlenkové mapy a metoda ano-ne.

Z výsledků je patrné, že učitelé na SzŠ používají více aktivizačních metod ve výuce než učitelé na VŠ a VoŠ. Jednou z přičin může být i fakt, že na VŠ a VOŠ tvoří podstatnou část teoretické výuky přednášky. Existují i další možné důvody například to, že na výuce klinických předmětů se podílejí 
kromě aprobovaných učitelů ošetřovatelství také lékaři, kteří nemají pedagogické vzdělání a s aktivizačními metodami pracují minimálně.

Na základě statistického vyhodnocení jsem zjistila, že podíl učitelů používajících aktivizační metody ve výuce je u obou pohlaví různý. Učitelky zařazovaly aktivizační metody častěji do výuky než učitelé. Jednou z možností, proč tomu tak je, se zdá být pragmatičnost mužů, nebot̉ ti, pokud mají osvědčenou metodu, tak ji používají a nesnaží se zavádět do praxe nic nového.

Ze získaných dat také vyplývá, že existuje vztah mezi délkou pedagogické praxe a používáním aktivizačních metod. Aktivizační metody používali častěji učitelé s pedagogickou praxí kratší než 10 let. Důvodem může být např. zavádění nových metod výuky do sylabů pedagogických fakult, ale i změny ve školství po roce 1989, zavádění rámcových vzdělávacích programů.

Z výsledků se mi však nepotvrdil statisticky významný rozdíl mezi upřednostněním tradičních výukových metod před metodami aktivizačními. Tradiční metody ve výuce upřednostňovalo 53,5\% učitelů. Příčinou upřednostnění tradičních výukových metod může být např. nechut učitelů používat nové postupy ve výuce, časová náročnost na přípravu učitele, časová náročnost některých metod, neznalost metod ze strany učitele. V Učitelských listech č.10 z roku 1998/1999 byl publikován výzkum zaměřený na souvislosti školního klimatu a metod výuky, který mimo jiné potvrdil, že na školách stále převažují tradiční výukové metody nad aktivizačními (Grecmanová, 2007). Mohu tedy konstatovat, že tato situace přetrvává i v roce 2006 . 
Je třeba si uvědomit, že nadměrné používání tradičních metod je pro studenty jednotvárné a nudné, což se může projevit pasivitou či nezájmem studentů při osvojování nových vědomostí a dovedností ve výuce, snížením jejich pozornosti či vyrušováním. Jedním z hlavních úkolů vyučujících je, aby studenti byli ve výuce aktivní a měli chut vyhledávat či získávat nové informace. Negativa však může přinést i nadměrné užívání aktivizačních metod, nebot studenty unavuje a nedochází k osvojení dostatečného množství informací. Myslím si, že pro pedagogickou praxi je velmi důležité, aby učitelé kombinovali metody tradiční s aktivizačními. Poměr kombinace by měl odpovídat povaze učební látky, věku a mentální úrovni studentů .

$\mathrm{V}$ roce 2005 se $\mathrm{V}$ ČR začal realizovat projekt za podpory Evropské Unie "Evropská integrace pro pedagogy s posílením aktivizačních metod ve výuce". Některé zkušenosti získané během tohoto projektu popisují autoři Tomáš Kotrba a Lubor Lacina ve své nové publikaci (Kotrba, Lacina, 2007). Faktem však zůstává, že na samotné aktivizaci nelze kritické myšlení stavět. Je důležité, aby se student naučil myslet, zpracovávat informace a učit se.

Na závěr bych chtěla podotknout, že existuje celá řada aktivizujících výukových metod, které jsou jednoduché a časově nenáročné a lze je použít také při edukaci klientů sestrou jak ve zdravotnickém zařízení, tak i v terénní péči a poradenské Činnosti. V rámci vysokoškolského studia ošetřovatelství mají budoucí sestry možnost se $s$ těmito metodami seznámit a naučit se s nimi pracovat v předmětech Pedagogika, Didaktika ošetřovatelství či Základy edukační činnosti. Záleží jen na sestře, zda tyto metody bude využívat při edukaci klienti̊, rodinných příslušníků, ale i zdravotnických pracovníků k dané 
ošetřovatelské problematice. Má-li sestra pracovat kvalitně a pohotově, měla by při své práci využívat aktivizační metody, které vedou k rozvoji kritického myšlení.

\section{Seznam bibliografických odkazů}

- GAVORA, P. 1988. Učenie sa z textu a metakognitívne procesy. Pedagogika, 1988, roč. 38, č. 6, s. 661-672.

- grecmanovÁ, H. 2007 Cyklus PANORAMA: Jaké jsou ve skutečnosti metody výuky na našich školách? [on line]. [cit. 2007-08-06]. Dostupné na www:

<http://www. ucitelské-listy.ceskaskola.cz>.

- GRECMANOVÁ, H., URBANOVSKÁ, E., NOVOTNÝ, P. Podporujeme aktivní myšlení a samostatné učení žáků. 1.vyd. Olomouc: Hanex, 2000. 8 s. ISBN 80-85783-28-2.

- KOTRBA, T., LACINA, L. 2007. Praktické využití aktivizačních metod ve výuce. 1.vyd. Brno: Barrister and Principal, 2007.188 s. ISBN 80-87029-12-7.

- SteEL, J. L., MEREDITH, K. S., TEMPLE, C., WALTER, S. 1998. Rozvíjení kritického myšlení. Čtením a psaním ke kritickému myšlení. Příručka II. 1998.

- ŠKRLA, P., ŠKRLOVÁ, M. 2003. Kreativní ošetřovatelský management. Praha: Advent-Orion, 2003. 477 s. ISBN 807219-014-8.

- ŠPirudovÁ, L., tomAnOVÁ, D., KUdlOVÁ, P., HAlmo, R. 2007. Multikulturní ošetřovatelství II. 1. vyd. Praha: Grada Publishing, 2005. s. 200-208. ISBN 80-247-1213-X.

\section{Kontakt na autory:}

PhDr. Magda Taliánová

Katedra ošetřovatelství

Fakulta zdravotnických studií Univerzita Pardubice

Průmyslová 395,530 10 Pardubice

Ústav preventivního lékařství, LF MU Brno 
magda.talianova@upce.cz

Mgr. Martin Forejt, PhD.

Ústav preventivního lékařství

Lékařská fakulta Masarykova univerzita Brno

Tomešova 12, 66243 Brno

mforejt@med.muni.cz 